\title{
Studies on the Cytogenetic and DNA Damage Induced by Theophylline in Different Tissues of Mice
}

\author{
Ayman A. Farghaly* and Kawser M. El Sherbeny \\ Department of Genetics and Cytology, National Research Centre, Dokki, Cairo, Egypt \\ Received May 31, 2005; accepted August 23, 2005
}

\begin{abstract}
Summary Theophylline (TH) is a methylxanthine widely used in clinical practice. The genotoxic effects of TH was investigated in mouse spleen, and spermatogonia cells. Also damage of DNA and molecular detection of apoptosis were applied. TH was administered orally as single dose of 25,50 , 75 and $120 \mathrm{mg} \mathrm{kg}^{-1}$ b.wt. and a multiple treatment with a daily dose of 25,50 and $75 \mathrm{mg} \mathrm{kg}^{-1}$ b.wt. for 3 and 7 successive days. TH induced a significant increase in the percentage of chromosomal aberrations in somatic and germ cells which was dose and time dependent.

Also, TH induced DNA damage and apoptosis in a dose and time dependent manner in mouse liver cells. However, induced DNA damage and apoptosis was maximally detected at a concentration of $120 \mathrm{mg} \mathrm{TH} \mathrm{kg}{ }^{-1}$ b.wt. after oral treatment for $1 \mathrm{~d}$.
\end{abstract}

Key words Theophylline (TH), Genotoxicity, DNA damage, Apoptosis.

The alkaloid Theophylline (TH a monohydrate of 1,3 dimethylxanthine Fig. 1) is a bronchodilator with wide-spread application in the treatment of asthma and bronchitis and as a relaxant of the involuntary muscles (Persson 1986). TH can also be used for the treatment of heart failure, headache, neonatal apnoea, neonatal respiratory syndrome, rhinitis and sleeping disorders (Reynolds 1996). TH readily crosses the placenta, so it is used as a bronchodilator during pregnancy (Rall 1980).

The mutagen/carcinogen potential of TH has been evaluated in short-term tests. The compound showed no mutagenic effect in bacterial strain TA 98 but a very weak effect in the TA 100 strain (Slamenova et al. 1986). It has exhibited a positive mutagenic action in E. coli (Timson 1975). The induction of cytogenetic damage to mammalian systems by TH has been indicated in a number of published reports. TH has the ability to induced sister chromatid exchanges among Chinese hamster ovary (CHO) and human lymphocyte cells in vitro (Kawachi et al. 1980, Morris and Heflich 1984) hamsters and mice bone-marrow cells in vivo (Renner 1982, MacFee 1991). Significant elevations of the number of chromosome abnormalities have been noted when TH was added to human lymphocyte at concentrations 500 or $750 \mu \mathrm{g} / \mathrm{ml}$ medium (Weinstein et al. 1975) and in cultures of mouse cell lines at concentrations of 3.2 or $6.3 \mathrm{mM}$ (Kodama et al. 1980).

$\mathrm{TH}$ belongs to the group of agent which potentiates the lethal effects of DNA damaging agents including X-rays, UV-light and many chemotherapeutic agents (Dezube et al. 1991). It has been shown to induce apoptosis in chronic lymphatic leukemia (CLL) cells both in vivo and in vitro (Binet et al. 1996, Mabed et al. 2004).

Exposure of mouse and human cells to TNF $(0.1-100 \mathrm{ng} / \mathrm{ml})$ as single agent for $48 \mathrm{~h}$ caused low or no lethality. The rates of cell

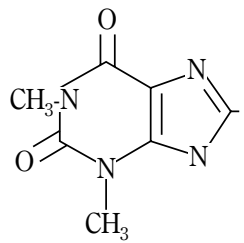

Fig. 1. The chemical structure of theophylline.

\footnotetext{
*Corresponding author, e-mail: farghaly5@yahoo.com
} 
death increased significantly when cells cultured with TNF for $24 \mathrm{~h}$ were exposed to the methylxanthine caffeine (2.0-20 mM) in a dose-dependent relationship (Belizario et al. 1993). Caffeine also, promoted the translocation of BAX protein from the cytosol of the mitochondria. In the setting of an overexpression of BAX, caffeine induced a conformational change of the protein and apoptosis in human H358 cell line (Dubrez et al. 2001).

\section{Materials and methods}

Male Swiss mice 9-12 weeks old were used. The mice used for any one experiment were selected from mice of similar age $( \pm 1$ week) and weight $( \pm 2 \mathrm{~g})$. TH was obtained from Mamfes Company of Chemicals and Drugs Arab Republic of Egypt.

The experimental design involved (I) A single oral treatment with the doses 25, 50, 75 and $120 \mathrm{mg} \mathrm{TH} \mathrm{kg} \mathrm{b}^{-1}$ b.wt. The sample were taken $24 \mathrm{~h}$ after oral treatment from spleen and spermatogonia cells of the mice for chromosomal aberration detection and from liver of the mice for DNA damage and apoptosis detection. (II) Multiple oral treatment for 3 and $7 \mathrm{~d}$ with the doses 25, 50 and $75 \mathrm{mg} \mathrm{TH} \mathrm{kg}{ }^{-1}$ b.wt. and sample were taken $24 \mathrm{~h}$ after the last treatment from the same organ as (I). Negative control with vehicle and positive control with $1 \mathrm{mg}$ mitomycin $\mathrm{C} \mathrm{kg}^{-1}$ b.wt. were tested.

Slide preparation and scoring

\section{Chromosomal aberrations}

The spleen was washed with medium RPMI 1640 and cut into small pieces. The cells were aspirated into a centrifuge tube and $0.07 \mathrm{M} \mathrm{KCl}$ was added. Chromosomes were prepared following the Yosida and Amano (1965). 100 well spread metaphases were analyzed/mouse.

For chromosomal aberrations in spermatogonia cells, testes were dissected out and processed according to Evans et al. (1964). 60 well spread metaphases were analyzed/mouse for spermatogonia cells.

The significance of the experimental versus control data was calculated using the $t$-test.

DNA damage and apoptosis detection

DNA damage and apoptosis was detected in liver cells of the mouse according to Hassab ElNabi (2000). Apoptotic bands apeared and located at $200 \mathrm{bp}$ and its multiple like 400, $600 \mathrm{bp}$ etc. The intensity of apoptotic bands could be measured by software Gel Pro program as maximum optical density values.

\section{Results}

Table 1 represents a detailed study of the effect of $\mathrm{TH}$ at different doses on the induction of aberrations in mouse spleen cells. The percentage of aberrations was dose and time dependent.

Table 2 demonstrates the types and mean percentage of chromosome aberrations in mouse spermatogonia cells after single and repeated doses of TH. The maximum percentage reached $14.0 \pm 0.83(P<0.01)$ after repeated oral treatment with $75 \mathrm{mg} \mathrm{TH} \mathrm{kg}{ }^{-1}$ b.wt. for 7 consecutive days compared with $3.80 \pm 0.83$ for negative control.

TH induced both structure and numerical aberrations in mouse spleen and spermatogonia cells (Tables 1, 2 and Fig. 2a, b).

As shown in Table 3 and Fig. 3 TH induced DNA damage and apoptosis in liver cells of the mice after treatment with different concentrations for different periods of time in a dose and time dependent manner. The optical density value at $200 \mathrm{bp}$ reached 79.7 after treatment of mice for $1 \mathrm{~d}$ with the highest dose comparing to 13.8 for the mice treated with the lowest dose for the same period of time with TH (Table 3). 


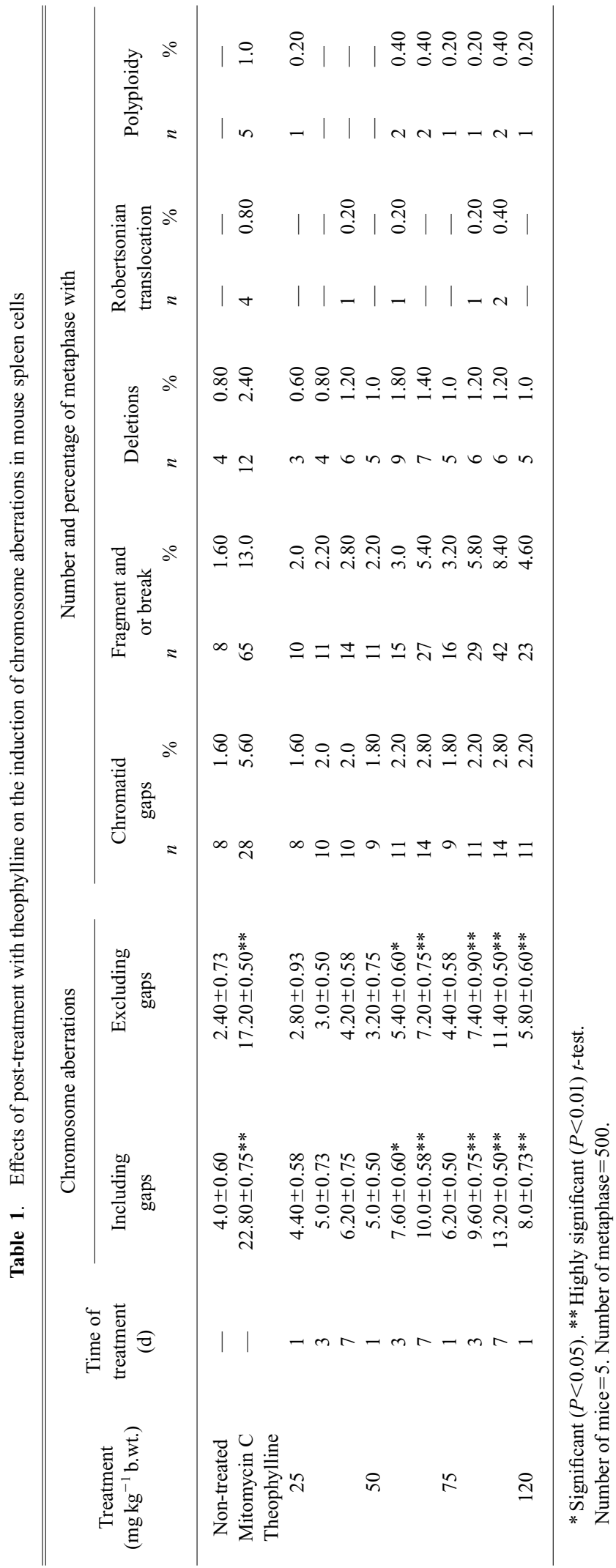




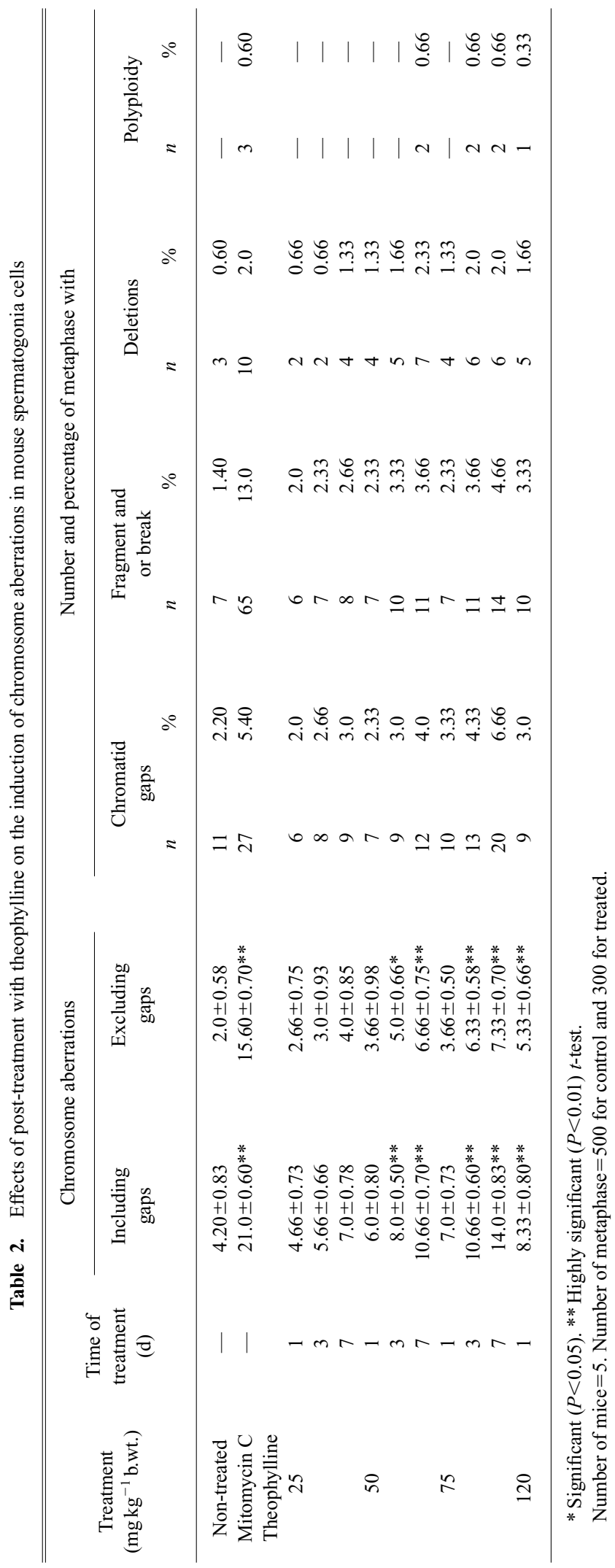




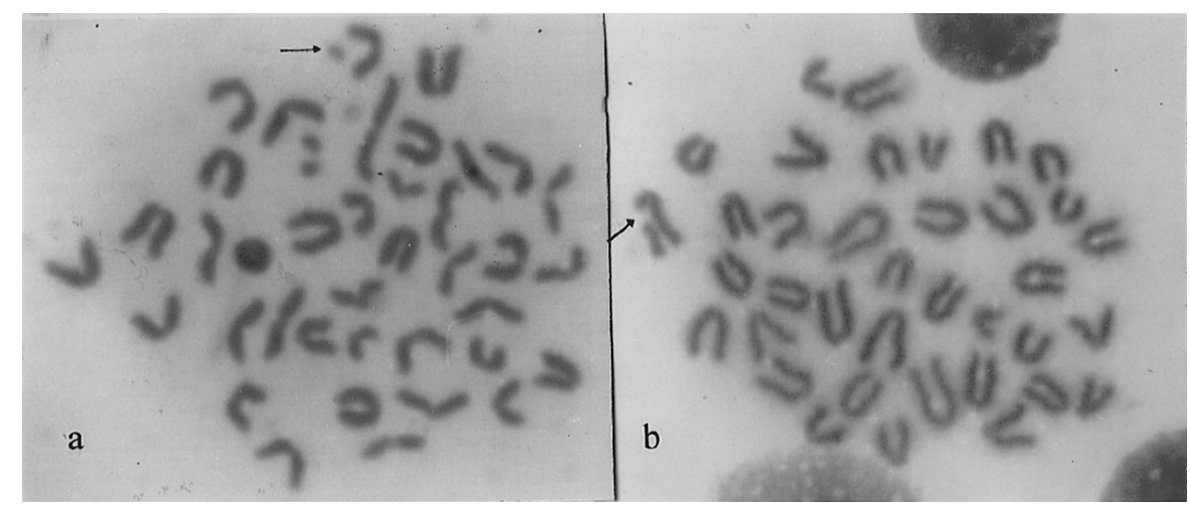

Fig. 2. Metaphases from mouse treated with different doses of $\mathrm{TH}$ showing a) fragment, in mouse spleen cells, b) break, in mouse spermatogonia cells.

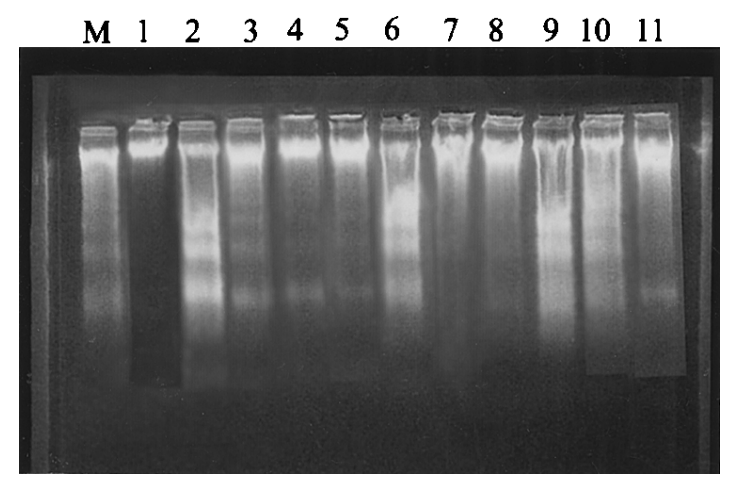

Fig. 3. Electrophoretic pattern of BNA damage in liver of mice treated with TH. M: 200, 400 and $600 \mathrm{bp}$ ladder, lane 1: control liver, lane 2: $120 \mathrm{mg} \mathrm{TH} \mathrm{kg}^{-1}$ b.wt. for $1 \mathrm{~d}$, lanes 3, 4, 5: $25 \mathrm{mg} \mathrm{TH} \mathrm{kg}^{-1} \mathrm{~b}$.wt. for 7, 3 and $1 \mathrm{~d}$ respectively, lanes $6,7,8: 50 \mathrm{mg} \mathrm{TH} \mathrm{kg}^{-1}$ b.wt. for 7, 3 and $1 \mathrm{~d}$ respectively, lanes 9 , 10, 11: $75 \mathrm{mg} \mathrm{TH} \mathrm{kg}^{-1}$ b.wt. for 7, 3 and $1 \mathrm{~d}$ respectively.

Table 3. Optical density of apoptotic fragments of DNA at 200, 400 and $400 \mathrm{bp}$ in liver of mouse treated with TH for different periods of time

\begin{tabular}{|c|c|c|c|c|c|c|c|c|c|c|c|}
\hline \multirow{3}{*}{$\begin{array}{l}\text { Molecular wt. } \\
\text { of apoptosis } \\
\text { (bp) }\end{array}$} & \multirow{3}{*}{ Control } & & \multicolumn{3}{|c|}{$1 \mathrm{~d}$} & \multicolumn{3}{|c|}{$3 \mathrm{~d}$} & \multicolumn{3}{|c|}{$7 d$} \\
\hline & & 120 & 75 & 50 & 25 & 75 & 50 & 25 & 75 & 50 & 25 \\
\hline & & (mg kg${ }^{-1}$ b.wt.) & \multicolumn{3}{|c|}{ (mg kg${ }^{-1}$ b.wt.) } & \multicolumn{3}{|c|}{ (mg kg ${ }^{-1}$ b.wt.) } & \multicolumn{3}{|c|}{ (mg kg${ }^{-1}$ b.wt.) } \\
\hline 600 & 1.5 & 90.1 & 9.1 & 4.2 & 4.3 & 86.1 & 22.8 & 13.8 & 89.3 & 61.2 & 11.5 \\
\hline 400 & 1.2 & 80.5 & 4.2 & 3.0 & 2.1 & 76.3 & 20.8 & 7.0 & 80.7 & 44.7 & 8.7 \\
\hline 200 & 1.8 & 79.7 & 15.3 & 25.2 & 13.8 & 73.4 & 19.2 & 14.2 & 75.3 & 38.9 & 37.6 \\
\hline
\end{tabular}

\section{Discussion}

The present work aimed to study the effect of $\mathrm{TH}$ for induction chromosomal aberrations in somatic and germ cells, as well as DNA damage and apoptosis in liver cells of mice after single and repeated oral treatment.

Our observations of chromosomal aberrations induced by TH in mouse spleen and spermatogonia cells show that TH is capable of inducing chromosomal aberrations in a dose and time depen- 
dent. These results are in the same line with MacFee (1991) who observed that under in vivo conditions, TH induced a significant increase in the number of SCE's in mouse bone-marrow cells when administered at $125 \mathrm{mg} \mathrm{kg}^{-1}$ b.wt. The same result was observed by Giri et al. (1999). They found that $\mathrm{TH}$ and theobromine having the ability to induce SCE significantly increased chromosomal aberrations in vivo in mouse bone-marrow cells after i.p. injection with the doses 12.5, 25 and $50 \mathrm{mg} \mathrm{kg}^{-1}$ b.wt.

Day et al. (1989) studied the chromosome aberrations and SCE's in the lymphocytes of normal individuals after in vitro exposure of TH. The cells were exposed to 3 different concentrations of $\mathrm{TH}(1,10,100 \mu \mathrm{g} / \mathrm{ml})$. A significant concentration effect of the drug was demonstrated for both CA and SCE. TH was also reported to induce SCE in the lymphocytes of patients receiving continued therapy with TH, and the frequency of SCE increased by increasing the time of treatment (Sinuses et al. 1992).

Pentoxifylline (a methylxanthine) induced chromosomal aberration, SCE and micromiclei after the treatment of cultivated Chinese hamster cells (V79) and human blood lymphocytes by different concentrations $(0.002-2.0 \mathrm{mg} / \mathrm{ml})$. In exposed V79 cells and lymphocytes as well, the dose dependent increase of the above mentioned end points were found (Bozsakyova et al. 2001).

The results of the present study showed that TH induced DNA damage and apoptosis in liver cells of mice, in a dose and time dependent manner. These observations are in agreement with Wiernik et al. (2004). They found that in vitro exposure of patients whose leukemic lymphocytes to $\mathrm{TH}(75-250 \mu \mathrm{g} / \mathrm{ml})$ resulted in dose and time dependent induction of apoptosis in $9 / 20$ patients studied. Also, in a dose dependent manner TH increased spontaneous apoptosis after $72 \mathrm{~h}$ in culture of 6 patients by a mean percentage of $80-90 \%$ in B-cell chronic lymphatic leukemia blood lymphocytes (control 20\%) (Binet et al. 1995).

Hirsh et al. (2004) found that TH at $20-25 \mu \mathrm{g} / \mathrm{ml}$ concentrations could induce moderate cell death in a variety of carcinoma cell lines derived from human ovarian, prostate and lung cancer and in granulosa cell line transformed by SV40 and Ras Oncogen.

The ability of TH to induce apoptosis may be through inhibition of cyclic nucleotide phosphodiesterases, thereby inducing the intracellular accumulation of cyclic adenosine monophosphate (cAMP) (Wiernik et al. 2004). It is well known that high intracellular levels of cAMP can effectively kill cells (apoptosis) (Webster and Anwer 1998). Or due to reduction of intracellular levels of Bcl-2 protein. Such a reduction was proportional to the extent of apoptosis (Hirsh et al. 2004).

From the results, the resistance of DNA damage and apoptosis in liver cells up to $7 \mathrm{~d}$ of treatment with TH may be due to inhibition of Bcl-2 gene which act as antiapoptotic (Milosevic et al. 2003, Hirsh et al. 2004) or increase the activity of kupffer cells in liver that share in apoptosis process (Hassab El-Nabi 2004).

Thus, the overall results of in vivo chromosomal aberrations assay in spleen and spermatogonia cells and DNA damage in liver cells of mice indicate that this drug has genotoxic effect. Taking the risk to humans into consideration by the wide use of this drug, these findings gives us attention to restrict the use of this drug for longer periods of time.

\section{References}

Belizario, J. E., Tilly, J. L. and Sherwood, S. W. 1993. Caffeine potentiates the lethality of tumor necrosis factor in cancer cells. Br. J. Cancer 67: 1229-1235.

Binet, J. L., Mentz, F., Baudet, S., Ouaaz, F. and Merle-Beral, H. 1995. In vitro induction of apoptosis in chronic lymphoid leukemia B lymphocytes by theophylline: Therapeutic applications. Bull. Acad. Natl. Med. 179: 1379-1392.

—, - and Merle-Beral, H. 1996. Apoptosis in blood diseases. Review new data. Hematol. Cell Ther. 38: 253-264.

Bozsakyova, E., Chalupa, I., Sebova, L. and Slamenova, D. 2001. Chromosomal aberrations, sister chromatid exchanges and micronuclei induced by pentoxifylline in in vitro cultivated Chinese hamster cells (V79) and human blood lymphocytes. Mut. Res., Oct. 18, 497: 63-70. 
Day, P., Shalaby, Z., Cohen, M. M., Wasserman, S. S. and Schwartz, S. 1989. Effects of theophylline on chromosomal breakage and sister chromatid exchange. Mut. Res. 224: 409-413.

Dezube, B. J., Fingert, H. J. and Lau, Ch. C. 1991. Methylxanthines: from cell biology to clinical oncology, In Perspectives on Cellular Regulation. From Bacteria to cancer, Willey-Liss, pp. 251-263.

Dubrez, L., Coll, J. L., Hurbin, A., Solary, E. and Favrot, M. C. 2001. Caffeine sensitizes human H358 cell line to P53-mediated apoptosis by inducing mitochondrial translocation and conformational change of BAX protein. J. Biol. Chem. 276: 38980-38987.

Evans, E. P., Breckon, G. and Ford, C. E. 1964. An airdrying method for meiotic preparation from mammalian tests. Cytogenetics 3: 289-294.

Giri, A. K., Das, M., Reddy, V. G. and Pal, A. K. 1999. Mutagenic and genotoxic effects of theophylline and theobromine in Salmonella assay and in vivo sister chromatid exchanges in bone-marrow cells of mice. Mut. Res. 444: 17-23.

Hassab El-Nabi, S. E. 2000. Rapid and simple technique for detection of total genomic damage (TGD) of DNA in human lymphocytes and its application on some mutagenic agents. J. Union. Arab. Biol. 14: 371-388.

- 2004. Molecular studies on the relationship between apoptosis and DNA damage induced by dexamethasone and flumox in liver and spleen of rat and human lymphocytes culture. J. Egypt. Ger. Soc. Zool. 45: 175-202.

Hirsh, L., Dantes, A., Suh, B. S., Yoshida, Y., Hosokawa, K., Tajima, K., Kotsuji, F., Merimsky, O. and Amsterdam, A. 2004. Phosphodiesterase inhibitors as anti-cancer drugs. Biochem. Pharmacol. 68: 981-988.

Kawachi, T., Yahagi, T., Kada, T., Tazima, Y., Ishidate, M., Sasaki, M. and Sugiyama, T. 1980. Cooperative programme on short-term assays for carcinogenicity in Japan. In: Montesano, R., Bartsch, H. and Tomatis, L. (eds.). Molecular and Cellular Aspects of Carcinogen Screening Tests, IARC Sci. Publ. No. 27, Lyon. pp. 323-330.

Kodama, F., Fukushima, K. and Umeda, M. 1980. Chromosome aberrations induced by clinical medicines. J. Toxicol. Sci. 5: 141-150.

Mabed, M., Aref, S., Fouda, M. and El-Sharawy, S. 2004. Chlorambucil plus theophylline vs. chlorambucil alone as a front line therapy for B-cell chronic lymphatic leukemia. Leuk., Lymphoma 45: 2029-2035.

MacFee, A. F. 1991. Chromosomal effects of theophylline measured in mouse marrow cells in vivo. Mut. Res. 264: 219-224.

Milosevic, J., Hoffarth, S., Huber, C. and Schuler, M. 2003. The DNA damage-induced decrease of Bcl-2 is secondary to the activation of apoptotic effector caspases. Oncogen 22: 6852-6856.

Morris, S. M. and Heflich, R. H. 1984. A comparison of the toxic and SCE-inducing effects of inhibitors of ADP-ribosome transferase in Chinese hamster ovary cells. Mut. Res. 126: 63-71.

Persson, C. G. A. 1986. Overview of effects of theophylline. J. Allergy Clin. Immunol. 78: 780-787.

Rall, T. W. 1980. Central nervous system stimulants. In: Gilman, A. G. and Goodman, L. S. (eds.). The Pharmacological Basis of Therapeutics, Macmillan, New York. pp. 593-607.

Renner, H. W. 1982. Sister chromatid exchanges induced by methylxanthines contained in coffee, tea and cocoa. Experientia 38: 600 .

Reynolds, J. E. F. 1996. Theobromine, Theophylline. In: Martindale (eds.). The Extra Pharmacopoeia, The Universally Acclaimed Source of Drug Information, The Pharmaceutical Press, London. pp. 1656-1665.

Sinuses, B., Broto, A., Suarez, M. A., Duce, F., Martinez-Berganza, A. and Bernal, M. L. 1992. Cytogenetic study in peripheral blood lymphocytes from asthmatic patients receiving continue therapy with theophylline. Mut. Res. 280: 271-277.

Slamenova, D., Budayova, E., Dusinska, M. and Gabelova, A. 1986. Results of genotoxicity testing of theophylline on bacteria and two lines of mammalian cells. Mut. Res. 33: 169-463.

Timson, J. 1975. Theobromine and theophylline. Neoplasma 32: 457-463.

Webster, C. R. and Anwer, M. S. 1998. Cyclic adenosine monophosphate-mediated protection against bile acid-induced apoptosis in cultured rat hepatocytes. Hepatology 27: 1324-1331.

Weinstein, D., Mauer, M., Katz, M. L. and Kazner, S. 1975. The effect of methylxanthines on chromosomes of human lymphocyte. Mut. Res. 31: 57-61.

Wiernik, P. H., Paietta, E., Goloubeva, O., Lee, S. J., Makower, D., Bennett, J. M., Wade, J. L., Ghosh, C., Kaminer, L. S., Pizzolo, J., Tallman, M. S. and Eastern Cooperative Oncology Group 2004. Phase II study of theophylline in chronic lymphocytic leukemia: a study of the Eastern Cooperative Oncology Group (E 4998). Leuk. 18: 1605-1610.

Yosida, T. H. and Amano, K. 1965. Autosomal polymorphism in laboratory, bred and wild Norway rats, Rattus norvigicus in Misima. Chromosoma 16: 658-667. 